\title{
POSTERIOR REVERSIBLE ENCEPHALOPATHY SYNDROME (PRES) IN CHILDREN UNDERGOING ALLOGENEIC STEM CELL TRANSPLANTATION
}

\author{
Aleksandra Pivkova Veljanovska, Zlate Stojanoski, Lazar Chadievski, \\ Irina Panovska Stavridis, Sanja Trajkova, Lidija Cevreska, Borche Georgievski \\ University Clinic for Haematology, Bone Marrow Transplantation Unit, Medical faculty, University Ss. Cyril and Methodius, \\ Skopje, Republic of Macedonia
}

Corresponding author: Ass. Prof PhD Aleksandra Pivkova Veljanovska, MD PhD, University Clinic for Haematology, Medical Faculty, Skopje, Head of Bone Marrow Transplantation Unit, Majka Tereza 17, 1000 Skopje, Macedonia, aleksandrapivkova@yahoo.com, Phone: +38972576463

\begin{abstract}
Posterior reversible encephalopathy syndrome (PRES) is one of the most serious complication after allogeneic stem cell transplantation in paediatric setting. It is most commonly reported as adverse event of immunosuppressive strategies during transplantation. We present a case of a 7 years old girl with myelodysplastic syndrome (MDS) treated with allogeneic stem cell transplantation (ASCT) at our department. Diagnosis of PRES was confirmed by imaging techniques during the first month after transplant and it was very likely connected with cyclosporine neurotoxicity. The aim of this article is to present our first experience in diagnosing and treating PRES in paediatric stem cell transplantation. Our experience showed that PRES is one of the reasons for higher transplant related mortality in children. Early prediction of factors contributing to PRES and closely monitoring of patient's vital signs, especially blood pressure, neurological status and vision are the main contributors for challenging the patient with another immunosuppressive agent that has less neurological toxicity. Still studies have to be initiated to confirm the influence of PRES on transplant outcome.
\end{abstract}

Keywords: PRES, stem cell transplantation, complications, outcome, cyclosporine

\section{INTRODUCTION}

PRES is clinical and radiological syndrome that commonly consists of parietal and occipital, posterior frontal cortical and subcortical oedema. The neurologic manifestations are variable, but frequently include headache, altered mental status, visual disturbances and seizures. Known associated causative agents include calcine urine inhibitor immunosuppressive drugs such as tacrolimus and cyclosporine. Although PRES has been associated with a widespread range of clinical conditions, namely infections, adverse drug events, autoimmune diseases, its onset after hematopoietic stem cell and solid organ transplantation remains the most commonly reported. [1] Historically,
PRES has proved to be generally reversible and associated with good clinical outcomes; however, severe complications, sometimes life-threatening, can also occur. Most reported cases of childhood PRES after hematopoietic stem cell or solid organ transplantation have been case reports or series across a broad spectrum of different transplant settings, and no clear consensus exists regarding how best to manage the syndrome. [2] The prompt recognition of PRES is crucial for starting symptomatic and life-supporting treatment and the proper management of the patient. Until now, a comprehensive assessment of predisposing factors for PRES in transplanted children has 
never been performed. [3] The statistical analysis of survival in paediatric allogeneic recipients revealed that PRES did not significantly influences the transplant outcome, but the larger series of transplanted children with PRES revealed better survival compared to those who did not have this complication during transplantation. [4] The aim of this article is to present our first experience as a transplant team with PRES onset in paediatric transplant setting.

\section{CASE REPORT}

We present a case of a 7 years old girl that initially presented with severe pancytopenia, with laboratory findings of pancytopenia and from biochemistry analysis high levels of lactate dehydrogenase (LDH) and ferritin. Clinically she experienced splenomegaly, symptoms of anaemia and haemorrhagic syndrome with hematomas on the skin of whole body and extremities and gingival bleeding. Important laboratory and clinical findings of the patient are presented in table 1 . The patient was diagnosed at the University children hospital in Skopje, Macedonia as myelodysplastic syndrome RAEB (MDS-RAEB, IPSS intermediate 2) and she was tested for a family HLA DNA identical donor. Since she revealed that she has an identical sibling (brother) in the family, she was referred for allogeneic stem cell transplantation. The patient parents signed all consent forms for diagnostic procedures and for stem cell apheresis of the donor and transplant procedure. The donor was 18 years old and received mobilization of peripheral blood stem cells (PBSC) by cytokines, granulocyte colony stimulating factor (G-CSF) in a dose of $5 \mathrm{mcg}$ / $\mathrm{kg}$ in a duration of 5 days. Apheresis was performed on day 5 . Sufficient number of CD34+ cells $/ \mathrm{kg}$ was gained only with one apheresis procedure and a total of $7.5 \times 106 / \mathrm{kg} \mathrm{CD} 34+$ cells were infused. The patient received Busulfan and Cyclophosphamide conditioning regimen $(\mathrm{Bu} \mathrm{Cy})$ that consisted of Busulfan $4 \times 0.8 \mathrm{mg} / \mathrm{kg}$ day 1 to 4 , Cyclophosphamide $50 \mathrm{mg} / \mathrm{kg}$ on days 5 and 6 . Standard GVHD immunosuppressive prophylaxis was applied with cyclosporine $5 \mathrm{mg} /$ $\mathrm{kg}$ and MTX on day $+1,+3,+6$ and +11 according to Seattle regimen..

\section{STATISTICAL ANALYSIS}

Statistical analysis was performed using SPSS for Windows, version 17 (USA). The Fisher-Free-
man-Halton exact test was used to determine the association between certain characters in group of patients. The Sperman Rang Order Correlation test was used to determine the correlation between two variables.

In order to test the significance of the difference between certain analyzed parameters, depending on the type and distribution of data, the parametric Student's t-test and ANOVA as well as nonparametric tests for independent samples (Mann Whitney $U$ test) were used. A level of $p \leq 0.05$ was considered statistically significant.

Table 1. Clinical and laboratory findings before and during allogeneic sibling stem cell transplantation

\begin{tabular}{|c|c|}
\hline Parameter & Value \\
\hline Age at transplant (years) & 7 \\
\hline Body weight (kg) & 25 \\
\hline Initial blood count & \\
\hline $\mathrm{Hgb} \mathrm{g} / \mathrm{dL}$ & 7.5 \\
\hline $\mathrm{WBC} \times 10^{9} / \mathrm{L}$ & 1.9 \\
\hline $\mathrm{Ne} \times 10^{9} / \mathrm{L}$ & 0.7 \\
\hline Plt $\times 10^{9} / \mathrm{L}$ & 5 \\
\hline $\mathrm{LDH} \mathrm{U} / \mathrm{L}$ & 1879 \\
\hline CMV status & \\
\hline Donor & Positive \\
\hline Patient & Positive \\
\hline Blood group & \\
\hline Donor & A Rh positive \\
\hline Patient & A Rh positive \\
\hline Apheresis & \\
\hline Number of procedures & 1 \\
\hline $\mathrm{CD} 34+/ \mathrm{kg} \times 10^{6}$ & 7.5 \\
\hline Day of engraftment & +15 \\
\hline GVHD gr I/II skin onset (day) & +20 \\
\hline $\begin{array}{l}\text { GVHD III/IV skin and } \\
\text { intestinal }\end{array}$ & +54 \\
\hline $\begin{array}{l}\text { PRES on set (day) } \\
\text { Fatal outcome (day) }\end{array}$ & $\begin{array}{c}+34 \\
+120\end{array}$ \\
\hline
\end{tabular}

Antibacterial, antimitotic and antiviral prophylaxis was administered according to the local policy. Prevention of haemorrhagic cystitis and venooclusive disease was also administered. During the transplant process she received irradiated blood products. Trilineage engraftment was detected on day +15 with $\mathrm{Hgb} 11.4 \mathrm{~g} / \mathrm{dL}$, WBC 1.9x109/L, Ne 0.7x109/L, Plt 26x109/L. First signs of skin GVHD gr I/II were noted on day +20 with palmar erythema of the skin. She started corticosteroid treatment. Progression of skin lesions was detected with maculopapular er- 
ythema of the face, palms, body affecting almost $50 \%$ of the skin. On day +34 the first neurological signs were noticed (headaches, sleeping disturbance, tremor, paraesthesia and epileptic seizures on 3 occasions). She was suspected for cyclosporine induced neurotoxicity and therefore cyclosporine was discontinued and replaced with tacrolimus in a dose of $0.15 \mathrm{mg} / \mathrm{kg}$ with methylprednisolone $4 \mathrm{mg} /$ $\mathrm{kg}$. The MRI of the brain showed high suspicion for PRES. After discontinuation of cyclosporine the neurological symptoms disappeared. She continued 15 days with the second line of immunosuppressive treatment with tacrolimus and corticosteroids and clinically improved. On day +53 she experienced second episode of neurologic symptoms with visual disturbance, intensive headaches, tachycardia, hypertension and seizures. She was discontinued from the tacrolimus and continued immunosuppression only with corticosteroids. She had MRI (Picture 1) that showed changes in terms of oedema in cortical and subcortical brain structures mainly due to PRES and vascular disseminated lesions. Due to GVHD progression she received treatment with anthytymocite globulin (ATG) and mycophenolate mofetil as third line immunosuppressive treatment. She was treated at the University Clinic of haematology until day +120 after transplantation when a fatal outcome due to GVHD gr III/IV skin and intestine occurred.
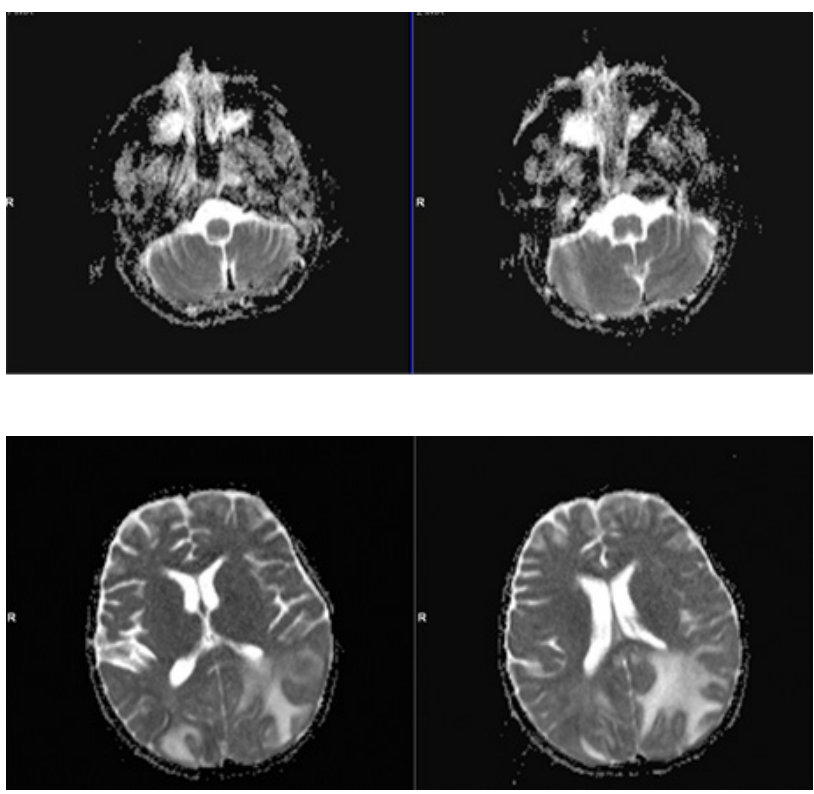

Picture 1. MRI findings of the 7 year old female patient with PRES

\section{DISCUSSION}

Neurotoxicity has emerged as an important transplant related mortality cause after stem cell transplantation for haematological malignant or non-malignant diseases in children. The calcineurin inhibitor, cyclosporine $\mathrm{A}(\mathrm{CSA})$ is the most frequently used agent for prevention of GvHD in both adult and paediatric patients. CSA is an established cause of post transplantation central nervous system (CNS) toxicity, typically characterized by posterior reversible encephalopathy syndrome (PRES). Even though neurological complications of CSA seldom result in mortality, the necessitated withdrawal of this potent agent can have major implications on clinical outcome particularly in the face of on-going $\operatorname{GVHD}(5)$. The case presented in this article was clear indication for treatment with allogeneic stem cell transplantation as first line treatment. Patient received standard conditioning regimen and standard immunosuppressive treatment schedule which consisted of CSA and MTX. The incidence of CSA neurotoxicity is between $4.6 \%$ to $11 \%$ in paediatric transplantation. Median time for developing of toxicity and PRES in most of the studies is 47.5 days (range 1 to 545 days). The onset of PRES in this case was on day 34 post transplant. Development of CSA-related neurotoxicity poses a complex clinical management situation as one of the most effective drugs in the treatment and prevention of GvHD needs to be discontinued promptly; sometimes in patients with on-going GvHD. As symptoms of CSA-neurotoxicity usually resolve over several days, re-challenge could be a viable option. Tacrolimus has been used as alternative agent in the event of CSA-related neurotoxicity but as it is also a CI, its use is similarly associated with significant neurotoxicity (6). Due to neurological symptoms in presented patient it was promptly evaluated and after diagnosis of PRES was confirmed, cyclosporine was discontinued although the patient developed gr I/II skin GVHD. Cyclosporine was changed with tacrolimus and the symptoms disappeared the second day after discontinuation. After two weeks on tacrolimus neurological symptoms were again detected, this time even worse and more persistent. So even tacrolimus was discontinued and patient left on corticosteroids. Evidence for the optimal approach of prophylaxis/management of GvHD when use of $\mathrm{CI}$ is contra-indicated is not available. In this case 
series, all but one patient received corticosteroids. In addition, as the combination of CSA and MMF is the most common GvHD prophylaxis regimen in our centre, the majority of patients were already receiving MMF at the time of development of CSA neurotoxicity. The efficacy of MMF as sole anti-GvHD agent is limited, and on its own it does not provide satisfactory GvHD prophylaxis or treatment. [7]

In the terms of diagnosis of PRES, MRI is still the gold standard. The typical lesion in PRES consists of vasogenic oedema, located predominantly in the subcortical white matter with frequent involvement of the cortex. These lesions show a high signal on T2-weighted images and fluid attenuated inversion recovery sequences. MRI showed to be an essential in diagnosis of PRES in this patient since she had two CT scans that could not be sufficient to confirm the diagnosis. [2]

Hypertension is one of the contributing factors to PRES and only $20 \%$ to $30 \%$ of paediatric patients with PRES had normal blood pressure when this condition occurred. Our patient revealed high blood pressure when treatment with calcine urine inhibitors started which is one of the most common adverse event in immunosuppression after ASCT. But hypertension lead to serious endothelial brain damage in our patient. Medication withdrawal often results in the alleviation of toxicity, despite a frequent lack of correlation in the literature between circulating blood levels of CNIs and the occurrence of PRES. In fact, CSA and tacrolimus levels have been found to be in the therapeutic ranges at the onset of many cases of PRES. This was the noted in our case, the levels of this two drugs were always in normal ranges before and after PRES occurrence. PRES occurring after HSCT must be distinguished from other acute neurologic complications, namely CNS infections, metabolic disturbances (electrolyte imbalances or multiple organ failure), cerebrovascular disorders, and CNS involvement by an underlying disorder (Table 2).

Treatment of neurological symptoms of PRES in children consists of early administration of antiepileptic drugs (AEDs) to control ongoing seizures. Benzodiazepines oral formulations or intravenous midazolam are most frequent used medications for this condition. Also lowering the blood pressure is very essential in the treatment. The duration of AED is controversial. Usually it is discontinued after 3 to 6 months after starting. Close follow up with laboratory monitoring, EEG an blood pressure monitoring can be very helpful in better resolving of this condition. [9]

Detection of intrising factors for PRES is one of the future challenges in paediatric transplant setting. Finding the biomarkers of disease such as circulating serologic biomarker possibly implicated in the development of PRES is one of the ongoing subject of researchers. Biomarkers

Table 2. Differential diagnosis of PRES

\begin{tabular}{|c|c|c|c|c|c|}
\hline & PRES & CNS infections & Neoplastic (PTLD) & Stroke & PML \\
\hline Type of transplant & All & All & All & $\begin{array}{l}\text { Ischemic heart>other } \\
\text { SOT>I5CT>Haemerchasic } \\
\text { HSCT>SOT }\end{array}$ & All \\
\hline $\begin{array}{l}\text { Timing after } \\
\text { transplantation }\end{array}$ & $\begin{array}{l}\text { Mostly <100 d in H5CT } \\
\text { May be delved in SOT }\end{array}$ & $\begin{array}{l}\text { Bacterial: < } 30 \text { days } \\
\text { Viral and others: }>30 \\
\text { days }\end{array}$ & Usually delayed & Perioperative or later & Delayed (> 6 months) \\
\hline Type of onset & $\begin{array}{l}\text { Acute } \\
\text { Seizures often }\end{array}$ & $\begin{array}{l}\text { Acute/subacute } \\
\text { Mental status changes }\end{array}$ & $\begin{array}{l}\text { subacute } \\
\text { Mental status changes }\end{array}$ & $\begin{array}{l}\text { Acute } \\
\text { Focal neurologic signs }\end{array}$ & $\begin{array}{l}\text { Subacute } \\
\text { Mental status changes }\end{array}$ \\
\hline $\begin{array}{l}\text { Presenting } \\
\text { signs/symptoms }\end{array}$ & $\begin{array}{l}\text { nonseovulsive and SE, } \\
\text { visual symptoms, } \\
\text { headache, mental } \\
\text { status changes }\end{array}$ & $\begin{array}{l}\text { Fever } \\
\text { Headache } \\
\text { Seizures }\end{array}$ & $\begin{array}{l}\text { Headache } \\
\text { Seizures }\end{array}$ & $\begin{array}{l}\text { Seizures ( often } \\
\text { becoiclenis) }\end{array}$ & Focal neurologic signs \\
\hline Location/pattern & $\begin{array}{l}\text { Subcortical } \\
\text { WM/cortical, usually } \\
\text { bilateral posterior } \\
\text { lobes } \pm \text { other lobes } \pm \\
\text { brainstem and } \\
\text { cerebellum }\end{array}$ & $\begin{array}{l}\text { WM focal, multifocal, } \\
\text { or diffuse = cortical } \\
\text { (depending on the } \\
\text { type of } \\
\text { microorganism) }\end{array}$ & $\begin{array}{l}\text { WM focal or multifocal } \\
\text { masses, meninges }\end{array}$ & $\begin{array}{l}\text { Ischemiccunilateral } \\
\text { WM/cortical } \\
\text { Haemerchagic: unilateral } \\
\text { bleeding }\end{array}$ & WM multifocal \\
\hline $\begin{array}{l}\text { Neurgimigiog } \\
\text { CT scan }\end{array}$ & Normal or low density & Normal or low density & Normal or low density & Low density or bleeding & Normal or low density \\
\hline Conventional MRI & High 12 signal & High 12 signal & Low or High 12 signal & High 12 signal & High 12 signal \\
\hline Contrast & Nenenchansiog & Nenenchanciog & Rerigh. enchancing & Nenenchanciog & Nenenchansiog \\
\hline $\begin{array}{l}\text { DWI } \\
\text { Laboratory findings }\end{array}$ & $\begin{array}{l}\text { Normal } \\
\text { Often } \\
\text { bugemagnesiemia }\end{array}$ & $\begin{array}{l}\text { Variable } \\
\text { Blood cultures and PCR } \\
\text { sometimes diagnostic }\end{array}$ & $\begin{array}{l}\text { Restricted } \\
\text { Often not significant }\end{array}$ & $\begin{array}{l}\text { Restricted } \\
\text { Ischemic: not significant } \\
\text { Haemerchasich: bleeding } \\
\text { diathesis }\end{array}$ & $\begin{array}{l}\text { Normal } \\
\text { Not signgificant }\end{array}$ \\
\hline CSF findings & Not significant & Often diagnostic & $\begin{array}{l}\text { Rarely diagnostic } \\
\text { (cytology) }\end{array}$ & Not significant & $\begin{array}{l}\text { PCR for JCV often } \\
\text { diagnostic }\end{array}$ \\
\hline EEG features & $\begin{array}{l}\text { Bythonic: spikes (NSCE), } \\
\text { PLEDs and/or slow in } \\
\text { the posterior regions }\end{array}$ & $\begin{array}{l}\text { Diffuse or focal } \\
\text { slowing }\end{array}$ & $\begin{array}{l}\text { Sometimes focal } \\
\text { slowing }\end{array}$ & $\begin{array}{l}\text { Unilateral PLEDs and/or } \\
\text { slowing }\end{array}$ & $\begin{array}{l}\text { Sometimes focal } \\
\text { slowing }\end{array}$ \\
\hline
\end{tabular}


of potential interest are: inflammatory cytokines, such as tumour necrosis factor a, interleukin-1, and interferon-g; markers of endothelial activation, such as p-selectin, e-selectin, intercellular adhesion molecule 1 , and vascular cell adhesion molecule 1; and endothelin-1 upregulation. [3]

A strategy for early detection, diagnosis and treatment of PRES in transplant setting is needed. Obviously this is post transplant complication that affects transplant outcome and changes the immunosuppressive treatment in the affected patients.

Although it is a rare complication, it can be concluded that PRES should be suspected with neurological symptoms in children undergoing HSCT and taking a calcineurin inhibitor. If confirmed by imaging, rigorous control of arterial blood pressure and discontinuation of the offending agent is recommended. We also conclude that it's safe to challenge the patient with a different calcineurin inhibitor once the PRES resolve.

\section{REFERENCES}

1. Goni Lee, Seung Eun Lee, Kyung-Ha Ryu, and Eun Sun Yoo. Posterior reversible encephalopathy syndrome in pediatric patients undergoing treatment for hemophagocytic lymphohistiocytosis: clinical outcomes and putative risk factors. Blood Res. 2013 Dec; 48(4): 258-265. doi: 10.5045/br.2013.48.4.258.

2. Riccardo Masetti, Duccio Maria Cordelli, Daniele Zama, Francesca Vendemini, Carlotta Biagi, Emilio Franzoni, Andrea Pession. PRES in Children Undergoing Hematopoietic Stem Cell or Solid Organ Transplantation. Pediatrics:135(5); 890-902 doi:10.1542/peds.2014-2325

3. D Zama, R Masetti, DM Cordelli, et all. Risk factor analysis of posterior reversible encephalopathy syndrome after allogeneic hematopoietic SCT in children. Bone Marrow Transplantation (2014) 49, 1538-1540
4. Javid Gaziev, Simone Marziali, Katia Paciaroni et all. Posterior Reversible Encephalopathy Syndrome after Hematopoietic Cell Transplantation in Children with Hemoglobinopathies. Biology of Blood and Marrow Transplantation Journal, 2017. 23:9;1531-1540. doi: 10.1016/j. bbmt.2017.05.033.

5. K Straathof, P Anoop, Z Allwood, J Silva, O Nikolajeva, R Chiesa, P Veys, PJ Amrolia and K RaoLong-term outcome following cyclosporine-related neurotoxicity in paediatric allogeneic haematopoietic stem cell transplantation. Bone Marrow Transplantation (2017) 52, 159-162 doi: 10.1038/bmt.2016.232.

6. Hammerstrom AE, Howell J, Gulbis A, Rondon G, Champlin RE, Popat U. Tacrolimus-associated posterior reversible encephalopathy syndrome in hematopoietic allogeneic stem cell transplantation. Am J Hematol 2013; 88: 301-305. doi: 10.1002/ajh.23402.

7. Johnston L, Florek M, Armstrong R, et al. Sirolimus and Mycophenolate Mofetil as Graft-versus-Host Disease Prophylaxis in Myeloablative, Matched Related Donor Hematopoietic Cell Transplantation. Bone marrow transplantation. 2012;47(4):581-588. doi:10.1038/bmt.2011.104.

8. Noè A, Cappelli B, Biffi A, Chiesa R, Frugnoli I, Biral E et al. High incidence of severe cyclosporine neurotoxicity in children affected by haemoglobinopaties undergoing myeloablative haematopoietic stem cell transplantation: early diagnosis and prompt intervention ameliorates neurological outcome. Ital J Pediatr 2010; 36:14. doi: 10.1186/1824-7288-36-14.

9. Erer B, Polchi P, Lucarelli G, Angelucci E, Baronciani D, Galimberti $\mathrm{M}$ et al. CsA-associated neurotoxicity and ineffective prophylaxis with clonazepam in patients transplanted for thalassemia major: analysis of risk factors. Bone Marrow Transplant 1996; 18: 157-162.

10. Stübgen J-P. Posterior reversible encephalopathy syndrome (PRES) after granulocyte-colony stimulating factor (G-CSF) therapy: a report of 2 cases. J Neurol Sci 2012; 321: 35-38. doi: 10.1016/j.jns.2012.07. 


\title{
Резиме
}

СИНДРОМ НА ПОСТЕРИОРНА РЕВЕРЗИБИЛНА ЕНЦЕФАЛОПАТИЈА (ПРЕС) КАЈ ДЕЦА ШТО СЕ ЛЕКУВААТ СО АЛОГЕНА ТРАНСПЛАНТАЦИЈА НА МАТИЧНИ КЛЕТКИ - ПРИКАЗ НА СЛУЧАЈ

\author{
Александра Пивкова Велјановска, Злате Стојаноски, Лазар Чадиевски, \\ Ирина Пановска Ставридис, Сања Трајкова, Лидија Чевреска, Борче Георгиевски
}

Универзитетска клиника за хематологија, Скопје, Медицински факултет, Скопје, Република Македонија

Синдромот на постериорна реверзибилна енцефалопатија (ПРЕС) е најсериозна компликација по алогена трансплантација на матични клетки кај педијатриски пациенти. Најчесто се реферира како несакан настан од имуносупресивните стратегии во текот на трансплантација. Приказ на случај на 7-годишно девојче со миелодиспластичен синдром (МДС) кое се лекува со алогена трансплантација на матични клетки во нашата институција. Дијагнозата на ПРЕС беше потврдена со радиолошки методи уште во текот на првиот месец по трансплантацијата и е резултат на циклоспоринска невротоксичност. Целта на трудот е да се презентира првото искуство во дијагноза и третман на ПРЕС во текот на педијатриска трансплантација на матични клетки. Нашето искуство покажа дека ПРЕС е најчестата причина за зголемување на морталитетот врзан за трансплантацијата кај децата. Раната предикција на факторите што се причина за ПРЕС и мониторирањето на виталните параметри кај болните, крвниот притисок, невролошкиот статус и вид, се значајни фактори што придонесуваат во промената на имуносупресивната терапија со избор на терапија со помала невротоксичност. Сѐ уште треба да се спроведат студии што ќе го потврдат влијанието на ПРЕС на посттрансплантацискиот исход.

Клучни зборови: ПРЕС, трансплантација на матични клетки, компликации, исход, циклоспорин 